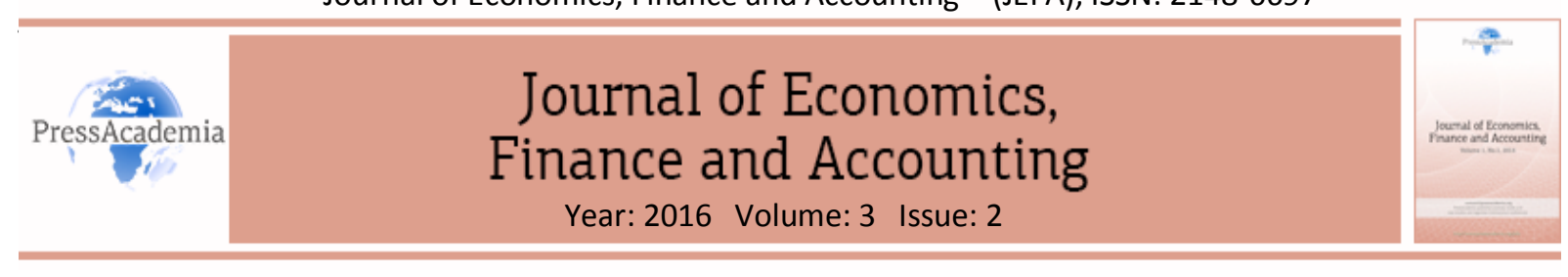

\title{
FIRM LEVEL DETERMINANTS OF FOREIGN PORTFOLIO INVESTMENTS IN TURKEY: A DYNAMIC PANEL REGRESSION ANALYSIS APPROACH
}

\section{DOI: 10.17261/Pressacademia.2016219775}

Yilmaz Yildiz ${ }^{1}$, Mehmet Baha Karan²

${ }^{1}$ Hacettepe University. yilmazyildiz@ hacettepe.edu.tr

${ }^{2}$ Hacettepe University. mbkaran@hacettepe.edu.tr

\begin{abstract}
The main aim of this study is to identify the investment preferences of foreign portfolio investors in Turkey. In this study, which comprises 151 non-financial firms listed in Borsa Istanbul between the years 2005-2014 and 1510 firm-year observations, dynamic panel regression methods are used to account for the consistent structure of the foreign investors' preferences over years. The findings of the study indicate that the market size is the most important determinant of the foreign investment decisions. In addition to the market size, foreign investors prefer firms with low level of liquidity. We do not observe any consistent and significant relationship between foreign investment ratio and other firm specific determinants. The findings of this study is consistent with the other similar studies in the literature. It is believed that due to asymmetric information problem between the local and foreign investors, foreign investors tend to invest in firms that they have more information about.
\end{abstract}

Keywords: foreign investors, portfolio investment, Turkey, firm characteristics

JEL Classification: F21, G11, C23

\section{TÜRKIYE'YE YAPILAN PORTFÖY YATIRIMLARININ FIRMA SEVIYESINDE BELIRLEYICILERI: BİR DINAMIK PANEL REGRESYON ANALIZI YAKLAŞIMI}

\section{ÖZET}

Bu çalışmanın temel amacı Türkiye'deki yabancı portföy yatırımcılarının yatırım tercihlerinin belirlenmesidir. 2005-2014 yılları arası Borsa İstanbul'a kote 151 finansal olmayan şirket ve yıllık bazda 1510 gözlemi kapsayan çalışmada yabancı yatırımcı tercihlerinin yıllar içerisindeki tutarlı yapısından dolayı dinamik panel regresyon yöntemleri kullanılmıştır. Çalışmadan elde edilen sonuçlar, yabancı yatırım kararlarını etkileyen en önemli değişkenin piyasa büyüklüğü olduğunu göstermektedir. Piyasa büyüklüğüne ek olarak, yabancı yatırımcılar likiditesi düşük şirketleri tercih etmektedirler. Yabancı yatırımcı oranı ile diğer firmaya özgü değişkenler arasında ise tutarlı ve anlamlı bir ilişki tespit edilememiştir. Elde edilen sonuçlar literatürdeki diğer çalışmalar ile uyumludur. Yerli ve yabancı yatırımcılar arasındaki asimetrik bilgi probleminden dolayı yabancı yatırımcıların hakkında daha fazla bilgi sahibi oldukları firmalara yatırım yapma eğiliminde oldukları düşünülmektedir.

Anahtar Kelimeler: yabancı yatırımcılar, portföy yatırımı, Türkiye, firma özellikleri JEL Sınıflandırması: F21, G11, C23 


\section{GíRiş}

Gelişmekte olan ülkelerin çoğunda tasarruf oranlarının yatıım ihtiyaçlarııın gerisinde olması nedeni ile bu ülkeler yabancı yatırımlara giderek daha fazla ihtiyaç duymaktadır. Özellikle 1990 'larda başlayan küreselleşme eğiliminden kaynaklanan uluslararası sermaye akımları gelişmekte olan ülkelerin büyümesinde önemli bir paya sahip olmuştur. Uluslararası sermaye hareketlerinin hız kazanması beraberinde uluslararası sermaye hareketlerinin belirleyicileri üzerindeki ilgiyi de arttırmıştır. Uluslararası sermaye, genel anlamda bir ülkeden başka bir ülkeye giren ve o ülkenin ekonomik gücünü ve mali yapısını etkileyen finansal ve teknolojik kaynaklar olarak tanımlanmaktadır. Yabancı girişi, ülkede yatııı için kullanılabilecek finansal kaynakları arttırmakta ve ülkedeki yerel sermayeden daha fazlasının tüketim ve yatııım için kullanılabilmesine imkan sağlamaktadır. Bu ülkelere akan yabancı sermaye; dış borçlar, portföy yatırımları ve doğrudan yatırımlar olarak sınıflandırılabilir (Gökkent, 1997: 9). Bunlardan portföy yatırımları diğerlerine göre çok daha kısa süreli olup, OECD tanımına göre doğrudan yatııımlar ve rezerv varlıklar kategorisine girmeyen bütün uluslararası hisse senedi ve borç yatırımlarıdır (OECD, Glossary).

Türkiye, diğer gelişmekte olan ülkelere paralel şekilde özellikle 2001 mali reformlarından sonra büyük ölçüde doğrudan yatııım ve portföy yatıımı elde etmiş ve yapılan çalışmalarda yabancı sermaye ile ülkenin ekonomik büyümesi arasında uzun süreli pozitif bir ilişki olduğu tespit edilmiştir (Kargı, 2014). Yılda yaklaşık 40 milyar dolara ulaşan portföy yatııımları Türk ekonomisinin istikrarı için oldukça önemli bir kaynak olmuştur. Ülkemize portföy yatırımları daha çok devlet tahvili, hazine bonosu ve hisse senedi yatırımı şeklinde girmektedir. Türkiye son 10 yıl içinde Borsa İstanbul şirketlerinin halka açık kısmının yaklaşı \%60-70'ine ulaşan portföy yatırımı elde etmiştir. Yabancı yatırımlarının artması, Borsa İstanbul'u daha likit bir piyasa yapmakta, borsada işlem gören şirketlerin değerini artırmakta, hepsinden önemlisi ülke ekonomisinin gelişmesine katkı vermektedir. Ancak portföy yatııımlarının doğası gereği, ekonominin yavaşladığı dönemlerde çıkan yabancı sermaye piyasaların oynaklığıı arttırmaktadır. Portföy yatııılarının hızla çıkması ülke ekonomisinin daralmasına ve krizi girmesine neden olabilmektedir. Bu durum yerli yatırımcıların ve politika yapıcılarının en istemediği sonuçtur. Nitekim ABD Merkez Bankasının 2009'dan bu yana uyguladığı parasal genişleme politikalarından geriye dönmesi, 2013 yılında ülkemize gelen portföy yatııımlarını geriye çevirmiş ve Türkiye kırılgan beşülke arasında gösterilmiştir (IMF, 2013). Bu nedenle Borsa İstanbul'a yatıım yapan yabancı yatırımcıları tanımak, onlarım firma tercihlerini anlamak, hem yerli yatııımcılar, hem de ekonomi yönetimleri için de oldukça önemlidir. Bu çalışmanın temel motivasyonu firma seviyesinde yabancı yatırımcıların tercihlerini belirleyerek yabancı yatırımcıları çekmek isteyen şirketlere yol gösterirken, aynı zamanda yerli yatııımcılara ve politika yapıcılarına bilgi vermektir.

Portföy yatırımlarından beklenen en büyük fayda ev sahibi ülkenin sermaye piyasaları üzerinde olacaktır. Yabancı yatıımlarla birlikte artan yatııımı sayısı ve işlem miktarı, misafir ülkenin menkul kıymet borsasının daha likit ve derin olmasına yardımcı olacaktır. Artan likidite ve derinlik aynı zamanda piyasanın daha etkin hale gelmesi şeklinde de yorumlanabilir. Artan likidite, yatırımcıların portföylerini de daha etkili bir şekilde yönetebilmelerine ve aynı zamanda istedikleri zaman olması gereken fiyattan varlıklarını nakde çevirebilmelerine olanak tanır. Etkin bir piyasada olması gereken fiyat ile gerçekleşen fiyat arasındaki fark en aza ineceğinden, ülke içerisindeki sermayenin dağılımı da daha verimli olacaktır. Artan etkinlik ve gelişmiş kurumsal yönetim ilkeleri, ev sahibi ülkenin daha güvenilir ve yatırım yapılabilir bir ülke olduğu ile ilgili yatırımcılara sinyal verecek ve bu durum uzun vadede portföy yatırımlarına ek olarak doğrudan yatıımların da artmasına, ve sonuç olarak ekonomik büyümenin hız kazanmasına neden olacaktır. Portföy yatırımlarının diğer bir faydası da, misafir ülkedeki finansal araçların çeşitliliğini artırarak, yatıımcıların portföy risklerini daha iyi yönetebilmelerine imkan tanımasıdır (Evans, 2002).

Portföy yatııımlarının ülke ekonomilerine etkisi genel olarak sermaye piyasaları aracılı̆̆ı ile olmaktadır. Portföy yatırımlarının ekonomik etkilerini değerlendirmeden önce, sermaye piyasalarının gelişimi ile ekonomik büyüme arasındaki ilişkiyi tartışmak önemlidir. Literatürde yapılan birçok çalışmada finansal piyasaların gelişimi ile ekonomik büyüme arasında pozitif bir ilişki tespit edilmiştir.

King ve Levine (1993) ve Levine ve Zervos (1996) finansal gelişme ile ekonomik büyüme arasında nedensel bir ilişki tespit etmişlerdir. Elde edilen sonuçlar, finansal gelişmelerin gelecek yıllardaki büyüme oranı, yatıım seviyesi ve yatıımların verimliliği üzerinde pozitif bir etkiye sahip olduğunu göstermektedir. Greenwood ve Jovanovic (1989) ve Bencivenga ve diğerleri (1992) piyasa likiditesi ile kaynak paylaşımı arasındaki ilişkiyi 
incelemiş ve likiditesi yüksek piyasalarda kaynakların marjinal faydası yüksek projelere aktarılacağını ve sonuç olarak ekonomik büyümenin hız kazanacağını belirtmişlerdir.

Gelişmiş sermaye piyasaları, yatırımcılara çeşitlendirme imkanı sunduğu için de önemlidir. Firmalar da benzer şekilde çeşitlendirme avantajından yararlanarak daha riskli projelere yatııı yaparak üretkenliklerini artırabilecektir. Ayrıca, gelişmiş sermaye piyasalarında yatıımcılar şirketlerle ilgili daha fazla bilgi sahibi olarak hem firmaların üzerindeki kontrolü artırıp onların daha karlı yatıımlara yönelmelerini sağlayacak hem de kendi sermayelerini, yoğun bilgi akışı sayesinde daha etkin yatırımlara yönlendirebileceklerdir. Başka bir ifadeyle sermaye piyasalarının gelişmesi firmalar ile yatırımcılar arasındaki bilgi asimetrisini azaltarak her iki tarafın da rasyonel karar almalarına yardımcı olacaktır. Hem firmaların hem de yatırımcıların aldığı etkin kararlar uzun vadede ekonomik büyüme üzerinde pozitif bir etki yaratacaktır (Hargis, 1998; Hargis ve Ramanlal, 1998).

Yukarıda bahsedilen piyasa gelişmişliğinin ekonomik büyüme üzerinde olumlu etkide bulunması ancak o piyasanın aktif olması ile mümkündür. Aktif bir piyasa için de en önemli şartlardan biri yatırımcı sayısının fazla olmasıdır. Yerli yatıımcıların yetersiz kaldığı durumda piyasaya yabancı yatıımcıların girmesi, piyasanın gelişmişlik seviyesini de doğrudan etkileyecektir. Sermaye piyasalarındaki yatıımcı sayısının artması hisse senedi fiyatlarının herhangi bir satış anındaki hassasiyetini azaltacak ve aynı zamanda hem halihazırdaki hem de potansiyel yatırımcıların çeşitlendirmeden elde ettikleri faydaları artıracak ve sonuç olarak da sermaye piyasaları gelişecektir (Pagano, 1989). Bir piyasanın büyüklüğü, piyasa içerisinde işlem gören hisse senetlerinin büyüklüğü, piyasada işlem gören hisse senedi sayısı ve aynı zamanda piyasadaki yatırımcı sayısı ile ilişkilidir. Sermaye varlıkları fiyatlama modelinin de öngördüğü gibi, uluslararası piyasalarla entegre olan piyasalarda yatırımcılar sadece ülke içi değil uluslararası çeşitlendirme avantajından da faydalanabilirler. Çeşitlendirme yoluyla riskin azalması, hisse senedinden beklenen getirinin de azalmasına ve hisse senedi fiyatının artmasına neden olur. Hisse senedi fiyatının artması da halka açık olmayan şirketleri de hisse ihracı konusunda motive edecektir (Hargis, 1998).

Bu çalışmanın temel amacı, özellikle gelişmekte olan ülkeler için çok fazla önem arz eden yabancı yatııımcıların firma seviyesinde yatııım tercihlerinin belirlenmesidir. Çalışmada 2005-2014 yılları arası Borsa İstanbul'a kote 151 finansal olmayan ve verilerine eksiksiz ulaşılabilen şirket analize dahil edilmiştir. Toplam örneklem büyüklüğü 1510 'dur. Çalışmada kullanılan bağımlı değişken hisse senetlerindeki yılsonu yabancı yatırımcı oranıdır (YYO). Çalışmada 8 ayrı firmaya özgü bağımsız değişken modele dahil edilmiştir. Çalışmada dinamik panel regresyon yöntemleri kullanılmıştır. Illk olarak dinamik EKK ${ }^{1}$ yöntemleri ile yabancı yatııımcı oranı tahmin edilmiş ancak modelde karşılaşılan içsellik probleminden dolayı dinamik araç değişkenli modeller ve $\mathrm{GMM}^{2}$ tekniği ile yabancı yatırımcı oranı tahmin edilmiştir. 2005 öncesi döneme ait yabancı yatırımcı verisine ulaşılamadığı için bu dönem analize dahil edilememiştir. Ayrıca, yabancı yatırımcı verisine sadece yıllık olarak erişilebildiği için bütün değişkenler de yıllık değerler temel alınarak değerlendirilmiştir. Son olarak, bazı firmalara ait verilere ulaşılamadığı için bu şirketler örneklem dışında bırakılmıştır.

Çalışmadan elde edilecek bulgular birçok açıdan önemlidir. İlk olarak Türkiye gibi tasarruf miktarının az olduğu ülkeler yatııı projelerinin finansmanı açısından yabancı sermayeye ihtiyaç duymaktadır. Bu bağlamda, yabancı sermayenin Türkiye'ye çekilebilmesi için yabancı yatırımcıların hangi şirketleri tercih ettiğinin bilinmesi gerek şirketler gerekse de politika yapıcılar açısından önemlidir. Ayrıca, çalışmada kullanılan örneklem periyodunun uzun (2005-2014) ve örneklem setinin büyük olması çalışmadan elde edilen sonuçların Türkiye adına genelleştirilebilmesi açısından önemlidir. Son olarak, çalışmada Türkiye'deki benzer çalışmalardan farklı olarak dinamik panel regresyon yöntemleri kullanılmıştır. Buradaki amaç, modelde karşılaşılabilecek içsellik problemlerini ortadan kaldırarak analiz sonuçlarının geçerliliğini arttırmaktır.

Çalışmada giriş bölümünden sonra ikinci bölümde Türkiye'ye yönelik sermaye hareketleri incelenecektir. Üçüncü bölümde yabancı yatırımcıların yatııım tercihleri ile ilgili yapılan önceki çalışmalar değerlendirilecek, dördüncü ve beşinci bölümlerde ise sırasıyla çalışmanın veri seti ve çalışmada kullanılan yöntemler açıklandıktan sonra çalışmadan elde edilen bulgular yorumlanacaktır. Son olarak altıncı bölümde genel bir değerlendirme ile birlikte çalışma sonlandırılacaktır.

\footnotetext{
${ }^{1}$ En Küçük Kareler

${ }^{2}$ Generalized Methods of Moments
} 


\section{TÜRKIYE'YE YÖNELIK ULUSLARARASI SERMAYE HAREKETLERi}

1980 sonrası uygulanan ekonomi politikaları ile giderek küresel bir siteme entegre olan Türkiye özellikle Türk parasının başka ülke paralarına çevrilebilir hale getirilmesi ile uluslararası sermaye akımlarından daha fazla faydalanmaya başlamıştır. Şekil 1'de Türkiye'ye yapılan doğrudan yatırımlar hem dolar cinsinden hem de doğrudan yatırımların GSYiH'ye oranı (sağ eksen) şeklinde gösterilmiştir. Şekil 1'den de görüldüğü üzere 1975 yılından 2000 yılına kadar Türkiye'ye yapılan doğrudan yatırımlar 1 milyar dolar seviyesinin altında kalmıştır. 1975-2000 yılları arasında doğrudan yatırım/GSYiH oranı en fazla \%0,61 ile Türkiye'nin serbestleşme sürecini tamamladığı ilk yıl olan 1989 yılına aittir. Türkiye her ne kadar 1989 yılında serbestleşme sürecini büyük ölçüde tamamlasa da, bu değişiklik serbestleşme sonrası ilk 10 yıllık sürede doğrudan yatırımlar açısından istenilen etkiyi yaratamamıştır. Türkiye'de yaşanan makroekonomik istikrarsızlıklar ve özellikle bu dönemde Latin Amerika ülkelerinin yüksek miktarda doğrudan sermayeye ev sahipliği yapmaları, Türkiye'yi ikinci plana iten nedenlerden biridir. Ayrıca, Çin ve Uzakdoğu'daki doğrudan yatırımı özendirici çalışmalar, Sovyetler Birliği'nin dağılması ve birlikte ayrılan ülkelerdeki özelleştirme politikaları Türkiye'yi yabancı yatırımcıların ilgili alanı dışına itmiştir.

\section{Şekil 1: Türkiye'ye Yönelik Doğrudan Yabancı Yatırımlar}

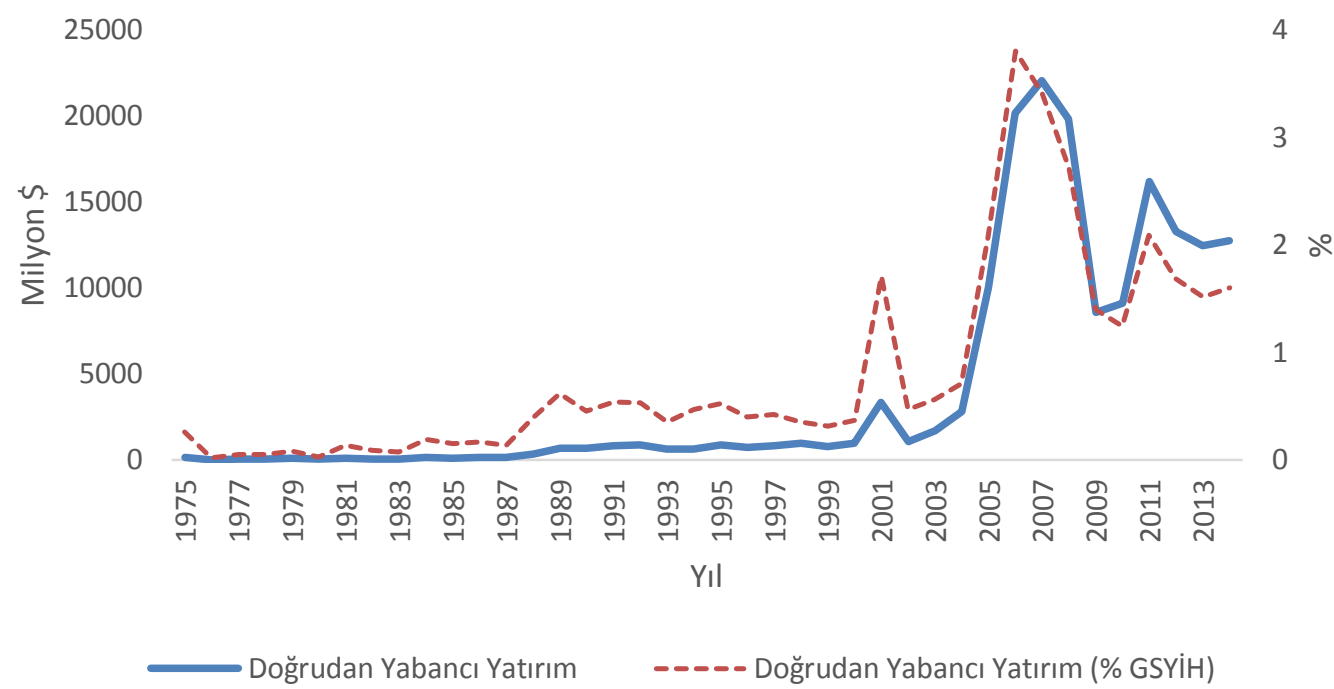

Kaynak: Dünya Bankası

2000 yılı sonrası doğrudan yatırımlara bakıldığında ise, özellikle 2006 ve 2007 yılları dikkat çekicidir. 2007 yılında doğrudan yatırımların GSYiH'ye oranı \%3,4 ile rekor seviyeye ulaşmıştır. 2008-2009 krizi ile birlikte tekrar azalmaya başlayan doğrudan yatırımlar 2011-2014 yılları arasında da dalgalı bir seyir izlemiştir. 2014 yılı itibariyle doğrudan yatırımların GSYiH'ye oranı \%1,60 seviyesindedir. Bu dönemde Türkiye'ye yapılan doğrudan yatırımlardaki artışın en önemli nedenlerinden biri 2000'li yıllarda yapılan özelleştirmelerdir. Her ne kadar 2001 krizi Türkiye'nin finansal anlamda güvenilirliğini azaltsa da, Türkiye kriz sonrası alınan tedbirlerle tekrar doğrudan yatırımların ilgi alanı içerisine girmiştir. Özellikle 2005 yılı ve sonrası enflasyon ve faiz oranları gibi makroekonomik göstergelerde iyileşmeler, Türkiye'ye yapılan doğrudan yatırımların önemli miktarda artmasına neden olmuştur.

Türkiye'ye yönelik portföy yatırımları incelendiğinde 1998, 2001 ve 2008 yıllarının olumsuz, 2005, 2010 ve 2012 yıllarının ise olumlu anlamda dikkat çektiği gözlenmiştir. 


\section{Şekil 2: Türkiye'ye Yönelik Portföy Yatırımları}

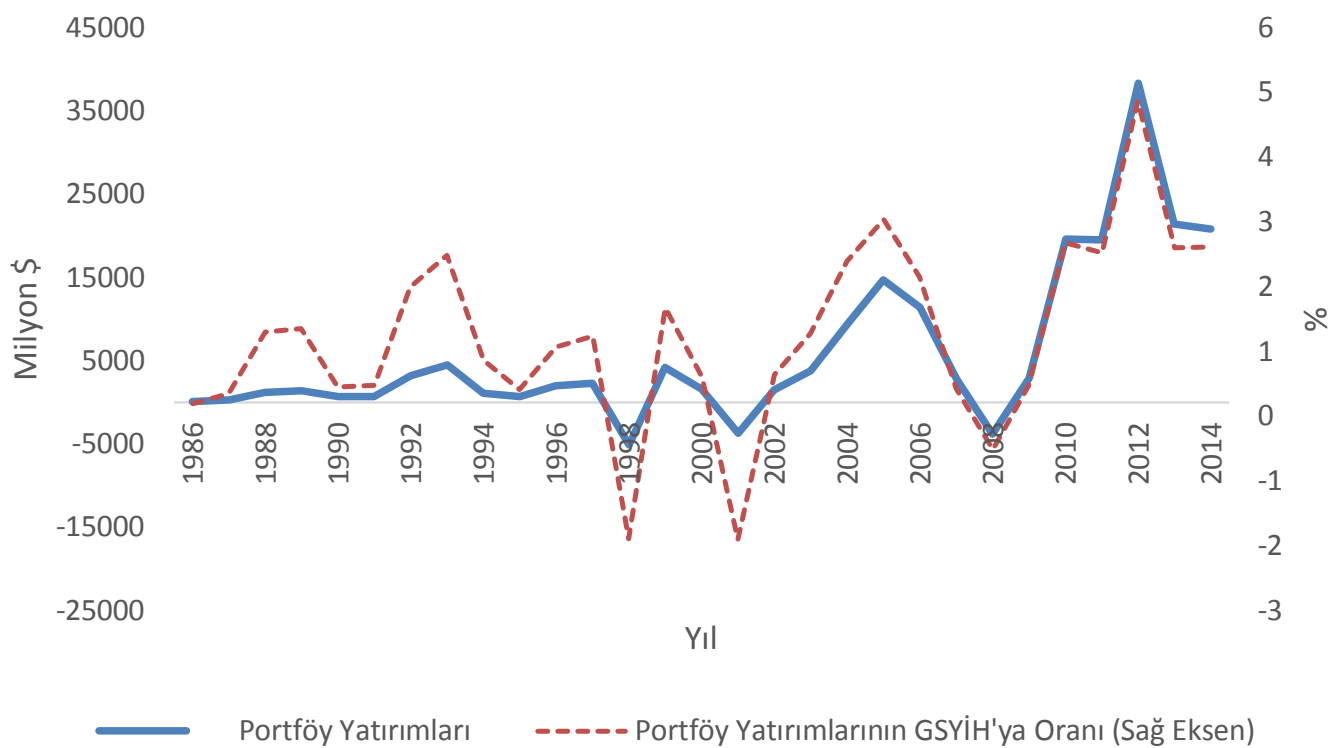

Kaynak: Dünya Bankası

1989 yılında tamamlanan Türkiye'nin serbestleşme süreci beklenen etkilerini ilk yıllarda gösterememiştir. Şekil 2 incelendiğinde her ne kadar 1989 yılında Türkiye yabancı portföy yatırımlarına tam olarak açık hale gelse de, 2005 yılına kadar portföy yatırımlarında önemli bir artış kaydedilememiştir. Grafikte ilk dikkat çeken nokta 1998 yılındaki sert düşüştür. 1997 yılında yaklaşık 2,3 milyar seviyesinde olan portföy yatırımları 1998 yılında -5 milyar seviyesine gerilemiştir. Portföy yatırımlarındaki bu gerilemenin en önemli nedenlerinden biri 1997 Asya Krizi'dir. 1997 yılına kadar gelişmekte olan piyasalara sermaye girişleri incelendiğinde, Asya piyasalarının gelişmekte olan ülkelere yönelik sermayenin neredeyse yarısını çektiği görülmektedir (IMF, 1998). Ancak 1997 Temmuz ayında Tayland'da başlayan mali kriz birçok Asya ülkesini etkilemiş, bu ülkelerin para birimleri önemli oranda değer kaybetmiştir. 1996 yılında gelişmekte olan ülkelere olan toplam sermaye girişi 208 milyar dolar seviyesindeyken, Asya Krizi sonrası bu miktar 1997 yılında 154,7 milyar dolara, 1998 yılında ise 100 milyar dolara gerilemiştir (IMF, 1998). Bu kriz, gelişmekte olan ülkelere güveni azaltmış ve Doğu Asya dışındaki birçok gelişmiş ve gelişmekte olan ülke piyasalarını etkilemiştir. Türkiye de bu krizin etkisiyle önemli miktarda sıcak para kaybına uğramıştır.

1999 ve 2000 yılları incelendiğinde, Türkiye'ye yönelik portföy yatırımlarında bir miktar toparlanma yaşansa da 2001 krizi ile birlikte görünüm tekrar negatife dönmüştür. 1999 ve 2000'li yıllarda görülen kısmi toparlanmada IMF ile imzalanan stand-by anlaşmasının önemli etkisi vardır. Enflasyonu düşürmeyi amaçlayan bu uygulamalar 2000 yılında sermaye girişlerini hızlandırsa da, 2000 sonlarında artan likidite sıkışıklığı ve sonrasında Şubat 2001 yılında artan politik gerginlik, 2001 yılında portföy yatııımlarının ciddi miktarda azalmasına neden olmuştur. Türkiye'ye yönelik portföy yatırımlarında en dikkat çekici gelişme 2005 yılında olmuştur. 2005 yılı içerisinde $A B^{\prime}$ den müzakereler konusunda tarih alınması yurtdışı yatırımcılarının ülkeye girişini hızlandırmıştır. Ayrıca gelişmekte olan ülkelerdeki yapısal reformlar ve ileriye dönük olumlu beklentiler, yabancı sermaye girişi konusunda önemli bir etkiye sahiptir (TCMB, 2005). 2008 yılının özellikle son çeyreğine gelindiğinde küresel krizin derinleşmeye başlaması ve finansal piyasalardaki tedirginlik Türkiye'yi çok fazla etkilemiştir. Buna bağlı olarak, küresel anlamda risk priminin yükselmesi, Türkiye'de sermaye akımları yavaşlatmıştır. 2012 yılına gelindiğinde ise ülkeye giren yabancı sermaye miktarında rekor seviyeye ulaşılmıştır. Kriz sonrası artan risk iştahı yabancı sermayenin gelişmiş ülkelerden gelişmekte olan ülkelere kaymasına neden olmuştur. Özellikle 2012 yılının ikinci yarısından itibaren portföy yatırımları hız kazanmıştır. 2013 yılına gelindiğinde ise risk iştahı dengelenmiş ve dalgalı bir seyir izlemiştir. Özellikle Aralık ayında yaşanan yerel gelişmeler nedeniyle Türkiye diğer gelişmekte olan ülkelerden negatif olarak ayrışmıştır. Sonuç olarak 2012 yılındaki rekor seviyenin altında kalınsa da 2013 yıl genelinde ülkeye önemli miktarda sermaye girişinin olduğu gözlenmiştir. 


\section{LITERATÜR TARAMASI}

Firma bazında yabancı yatırımcı kararını etkileyen değişkenleri belirlemeye yönelik ilk çalışmalardan biri Kang ve Stulz (1997)'a aittir. Çalışmada 1975-1991 yılları arasında Japonya Borsası'nda işlem göre hisse senetleri analize dahil edilmiştir. Çalışmada yabancı yatırımcı kararı üzerinde etkili olduğu düşünülen 8 açıklayıcı değişken kullanılmıştır. Her yıl için yapılan regresyon analizleri sonucunda 16 yıl boyunca anlamlı çıkan tek değişken piyasa değeri yani büyüklük değişkenidir. Başka bir ifadeyle, diğer değişkenler kontrol edildiğinde yabancı yatırımcılar piyasa değeri büyük şirketleri tercih etmektedirler. Kaldıraç değişken, 16 yılın 12'sinde yabancı yatırımcı oranı ile negatif bir ilişkiye sahiptir. Bu sonuç yabancı yatırımcıların genel olarak düşük kaldıraç oranına sahip şirketleri tercih ettiğini ifade etmektedir. Özetle, çalışmadan elde edilen sonuçlar, yabancı yatırımcıların yatırım kararları üzerinde en fazla etkiye sahip faktörün, piyasa değeri yani büyüklük olduğunu göstermektedir.

Kang ve Stulz'un 1997 yılındaki çalışmasına benzer şekilde Dahlquist ve Robertsson (2001) İsveç Borsası'na yatırım yapan yabancı yatırımcıların yatırım tercihlerini 1991-1997 yılları arasını kapsayacak şekilde incelemişlerdir. Çalışmadan elde edilen sonuçlar, yabancı yatırımcıların yüksek piyasa değeri ve cari orana sahip şirketleri tercih ettiğini göstermektedir. Temettü oranı ile yabancı yatırımcı oranı arasında ise negatif bir ilişki vardır. Analize şirketlerin ihracat oranı, işlem hacmi, ortaklık yapısı ve hisse senetlerinin başka ülke piyasalarında işlem gördüğünü belirten kukla değişken eklendiğinde ise yabancı yatırımcı oranı ile piyasa değeri arasındaki ilişki anlamsız hale gelmiştir. Yabancı yatırımcı oranı ile ihracat oranı ve işlem hacmi arasında pozitif bir ilişki tespit edilmiştir. Ayrıca şirketlerin başka ülke piyasalarında işlem gördüğünü belirten kukla değişkenin katsayısı da pozitif ve anlamlıdır. Son olarak, yabancı yatırımcıların konsantre bir ortaklık yapısına sahip şirketlere portföylerinde daha az ağırlık verdikleri tespit edilmiştir.

Lin ve Shiu (2003) yabancı yatırımcıların yatırım tercihlerini 1996-2000 yılları arasında Tayvan piyasası üzerinde incelemiştir. Çalışmadan elde edilen sonuçlar yabancı yatırımcıların piyasa değeri, ihracat oranı ve betası yüksek, defter değeri/piyasa değeri oranı düşük şirketleri tercih ettiğini göstermektedir.

Edison ve Warnock (2004) ABD'deki yatırımcıların 1997 yılı itibariyle gelişmekte olan ülkelerdeki yatırım tercihlerini içeren çalışmalarında, önceki çalışmalarda kullanılan değişkenlere ek olarak ilgili hissenin ABD borsalarında kote olma durumunu da açıklayıcı değişken olarak analize dahil etmişlerdir. Elde edilen sonuçlar yabancı yatırımcıların hem kendi ülkelerinde hem de ABD'de işlem gören hisse senetlerini tercih ettiğini göstermektedir.

Yabancı yatırımcıların yatırım tercihlerini inceleyen bir diğer çalışmada Aggarwal ve diğerleri (2005) literatürdeki diğer çalışmalardan farklı olarak ABD'deki aktif bir şekilde yönetilen yatırım fonlarının gelişmekte olan ülkelerdeki hisse senetleri üzerindeki yatırım tercihlerini etkileyen faktörler üzerinde durmuşlardır. 2002 yılı verisinin kullanıldığı çalışmada 114 yatııı fonu analize dahil edilmiştir. Önceki çalışmalardan farklı olarak, analize firmaların muhasebe uygulamalarının ve yatırımcı koruma politikalarının sağlamlığını gösteren değişkenler de eklenmiştir. Çalışmadan elde edilen sonuçlar, ABD yatırım fonlarının şeffaf muhasebe uygulamaları yürüten ve $\mathrm{ADR}^{3 \text { ' }}$ ye sahip şirketleri tercih ettiğini göstermektedir.

Leuz ve diğerleri (2010) 29 gelişmiş ve gelişmekte olan ülke ve 4409 şirketi içeren çalışmasında, ABD'de ikamet eden yatırımcıların diğer ülkelerdeki yatırım tercihleri ile şirketlerin ve ülkelerin kurumsal yönetim ilkeleri arasındaki ilişkiyi incelemiştir. Tobit regresyon analizinin kullanıldığı çalışmadan elde edilen bulgular, yabancı yatırımcıların zayıf kurumsal yönetim uygulamalarına sahip şirketlere yatırım yapmadıklarını göstermektedir. Başka bir ifadeyle, azınlık haklarının korunduğu şirketlerde yabancı yatırımcı sahiplik oranı daha fazladır. Yapılan ek testler, yabancı yatırımcıların kar yönetimi uygulamaları yapan şirketleri tercih etmediklerini göstermektedir.

Leuz ve diğerleri (2010)'nin çalışmasına benzer bir çalışmada, Giannetti ve Simonov (2006) birçok yatırımcı grubunun hisse senedi tercihlerinde şirketlerin kurumsal yönetim kalitesini dikkate alıp almadığını araştırmıştır. Çalışma sonucunda, yabancı yatırımcıların kaliteli kurumsal yönetime sahip şirketlere yatırım yapma eğiliminde oldukları tespit edilmiştir. Ayrıca, yabancı yatırımcıların sistematik riski yüksek şirketleri tercih ettikleri de çalışma sonucunda elde edilen bulgulardan bir diğeridir.

\footnotetext{
${ }^{3}$ American Depositary Receipt
} 
Liljeblom ve Löflund (2005) 1993-1998 yıllarını kapsayan çalışmasında Finlandiya piyasasında işlem gören hisse senetlerindeki yabancı yatırımcı sahiplik oranını belirleyen faktörleri incelemiştir. Çalışmadan elde edilen sonuçlar, yabancı yatırımcıların temettü verim oranı düşük, piyasa değeri, likiditesi ve karlılığı yüksek şirketleri tercih ettiğini göstermektedir.

Şirketlerin kurumsal yönetim kalitesinin yabancı yatırımcı tercihleri üzerindeki etkisini inceleyen bir diğer çalışmada Min ve Bowman (2015), 1999-2003 yılları arasında Güney Kore piyasasında işlem gören şirketleri incelemiştir. Çalışmada, kurumsal yönetim kalitesi dışarıdan atanan yöneticilerin sayısının toplam yönetim kurulu üyesi sayısına oranı ve azınlık haklarının korunması ile ilgili olarak ise kontrol gücü olan payların toplam paylara oranı kullanılmıştır. Firma büyüklüğü ve yerel önyargıları temsil eden kontrol değişkenlerinin de kullanıldığı analiz sonuçlarına göre şirketlerin kurumsal yönetim kalitesi arttıkça, yabancı yatırımcı oranının da arttığı gözlenmiştir.

Türkiye de ise Kandır (2008), 2000-2004 döneminde en büyük 1000 şirketi üzerinde yaptığı çalışmada, yabancı yatırımcıların yatırım tercihlerini incelemiştir. Portföy analizi ve regresyon analizlerinin kullanıldığı çalışmada, bağımlı değişken şirketlerin yabancı sermaye oranı; bağımsız değişkenler ise kaldıraç, ihracat oranı, personel sayısı, aktif karlılık, öz sermaye karlılığı, net satışlar ve şirketlerin IMKB'de işlem gördüğünü belirten kukla değişkenlerdir. Elde edilen sonuçlar, şirketlerin satış hacmi, karlılığı ve ihracat oranı ile yabancı yatırımcı oranı arasında pozitif anlamlı bir ilişki olduğunu göstermektedir.

\section{VERi}

Çalışmada 2005-2014 yılları arası Borsa İstanbul'a kayıtlı, finansal olmayan ve analizde kullanılacak olan bütün değişkenlere ait bilgileri 2005-2014 dönemleri arasında eksiksiz, toplam 151 şirket analize dahil edilmiştir. Toplam örneklem büyüklüğü 1510'dur. Bir sonraki bölümde açıklanacak olan analizlerde gecikmeli değerlerin de kullanılacak olmasından dolayı veri seti olarak düzenli panel tercih edilmiştir. Yabancı Yatırıma Oranı ve ihracat değişkeni dışındaki bütün değişkenlere ait veriler Datastream ve Datastream Eikon veri tabanından

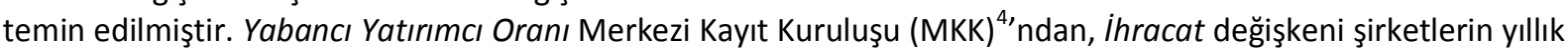
faaliyet raporları incelenerek elde edilmiştir.

Bağımlı Değişken: Çalışmada kullanılan bağımlı değişken olan Yabancı Yatırımcı Oranı (YYO)'dır. Bu oran yılsonu itibariyle hisse senetlerine yatırım yapan yabancı yatırımcıların bakiyeli hesaptaki yatırım tutarının, toplam yatırımcı bakiyeli hesap tutarına bölünmesi ile elde edilmiştir. Başka bir ifadeyle yabancı yatırımcı oranı, bir hissedeki yabancı yatırımcıların varlık değerinin bütün yatırımcıların toplam varlık değerine olan oranıdır. Burada önemli olan nokta yabancı yatırımcı oranının hisse senetlerinin sadece halka açık kısmı kullanılarak hesaplanmasıdır. Diğer bir ifadeyle, stratejik yani halka açık olmayan hisseler yabancı yatırımcı oranı hesaplanırken dikkate alınmamalıdır. Aksi takdirde yabancı yatırımcı oranı olduğundan daha düşük gözükecektir (Dahlquist ve diğerleri, 2003). Yabancı yatırımcı oranı verisi Merkezi Kayıt Kuruluşu'ndan (MKK) temin edilmiştir. ${ }^{5}$ MKK yabancı yatırımcı oranını şirketlerin halka açıklık oranı üzerinden verdiği için ek bir düzeltmeye gerek duyulmamıştır.

\section{Bağımsız Değişkenler}

Çalışmada literatürdeki diğer çalışmalara benzer şekilde 8 adet firmaya özgü değişken açıklayıcı değişken olarak analize dahil edilmiştir. Bu değişkenler şunlardır:

$P D$ : Çalışmada kullanılan ilk kontrol değişkeni firma büyüklüğüdür. Firma büyüklüğü olarak firmanın ilgili sene sonu piyasa değerinin doğal logaritması kullanılmıştır. Firmanın sene sonu piyasa değeri ise firmaya ait ilgili yılın son iş günü oluşan piyasa fiyatı ile hisse senedi sayısı çarpılarak hesaplanmıştır. Literatürde yapılan çalışmaların birçoğunda firma büyüklüğü ile yabancı yatırımcı oranı arasında pozitif bir ilişki tespit edilmiştir. Kang ve diğerleri (2010) Kore piyasası üzerinde 2000-2004 yılları arasını kapsayan çalışmalarında firma büyüklüğü ile yabancı yatırımcı arasında anlamlı pozitif bir ilişki tespit etmişlerdir. Hao (2004) Japonya sermaye piyasasında 1975-2001 yılları arasında yabancı yatırımcı oranını belirleyen faktörleri inceleyen çalışmasında yabancı

\footnotetext{
${ }^{4}$ MKK sermaye piyasası araçlarının ilgili hesaplarda kaydedildiği, bunlar üzerindeki hakların izlendiği kanunla görevlendirilmiş merkezi bir yapıdır. MKK bu yapısıyla Türkiye'nin merkezi sermaye araçları saklama merkezidir.

${ }^{5}$ Yabancı yatırımcı oranı verisi sadece yıllık ulaşılabilir olduğu için bütün analizler yıllık veriler üzerinden yapılmıştır.
} 
yatırımcıların büyük firmaları tercih ettiğini tespit etmiştir. Benzer şekilde Liljeblom ve Löflund (2005) 19921997 yılları arasında 227 şirketi kapsayan çalışmalarında Helsinki Borsası'nda yabancı yatırımcıların daha çok büyük firmaları tercih ettiklerini tespit etmişlerdir.

Kaldıraç: Çalışmada kullanılan diğer bir kontrol değişkeni kaldıraç oranıdır. Kaldıraç oranı olarak yılsonu toplam yükümlülüklerin toplam kaynaklara oranı kullanılmıştır. Kaldıraç oranı, varlıkların ne kadarlık kısmının yabancı kaynaklarla finanse edildiğini göstermektedir. Özellikle Türkiye gibi gelişmekte olan ülkelerde finansal piyasaların istikrarlı olmamasından dolayı birçok şirket borçlarını ödeyememe riski ile karşı karşıya kalabilmektedir. Literatürdeki birçok çalışma özellikle kriz dönemlerinde borçlanma oranı ile firma performansı arasındaki negatif ilişkiyi ortaya koymaktadır. Asgharian (2003), Opler ve Titman (1994) piyasaların düşüşe geçtiği dönemlerde borçlanma oranı yüksek şirketlerin borçlanma oranı düşük şirketlere oranla daha düşük satış büyüme oranı ve hisse senedi getirisi elde ettiğini tespit etmişlerdir. Borçlanma oranı yüksek olan şirketlerin iflas etme intimalinin yüksek olması ve bu şirketlerin hisse senetlerinin özellikle kriz dönemlerinde negatif getiriler elde ettikleri için yabancı yatıımcıların borçlanma oranı düşük şirketleri daha fazla tercih edeceği düşünülmektedir.

Karlıık: Çalışmada şirketlerin faaliyet karıııı̆ının bir göstergesi olarak yılsonu faiz, amortisman (yıpranma payı) ve vergi öncesi karın (FAVÖK) toplam varlıklara oranı kullanılmıştır. Literatürde karlıık ve yabancı yatııımcı oranı arasındaki ilişkiyi ele alan çalışmalarda birbiri ile çelişen sonuçlar elde edilmiştir. Kang ve diğerleri (2010) yabancı portföy yatırımları ile firma karlıı̆̆ı arasında anlamlı bir ilişki bulamamıştır. Liljeblom ve Löflund (2005) ise yabancı yatırımcıların aktif karlılığı yüksek şirketleri tercih ettiğini belirtmiştir.

Likidite: Çalışmada likidite ölçütü olarak kısa vadeli varlıkların kısa vadeli yükümlülüklere oranı (cari oran) kullanılmıştır. Cari oran firmanın kısa vadede borçlarını karşılayabilme gücünü ve beklenmedik ekonomik durumlarda firmanın faaliyetlerini sürdürebilme kabiliyetini ifade eder. Özellikle finansal istikrarı düşük olan ülkelerde yabancı yatırımcıların likiditesi yüksek firmaları tercih edeceği düşünülmektedir.

$P D / D D$ : Fama ve French (1992) piyasa değeri/defter değeri oranını hisse senetlerinin getirilerini açıklayan ve beta katsayısından daha iyi bir riske göre getiri değişkeni olduğunu ifade etmiştir. Piyasa değeri/defter değeri büyük olan şirketler büyüme potansiyeli olan şirketler olduğu için yabancı yatırımcıların büyük piyasa değeri/defter değeri oranına sahip şirketleri tercih edeceği tahmin edilmektedir.

Temettü: Çalışmada temettü dağııım oranı olarak ilgili firmanın yıl boyunca dağıttığı temettü miktarı sene sonu fiyatına bölünerek bulunmuştur. La Porta ve diğerleri (2000) 33 ülke üzerinde yaptıkları çalışmada iyi kurumsal yönetime sahip şirketlerin daha fazla temettü ödemesi yaptıklarını tespit etmişlerdir. Leuz ve diğerleri (2010) 29 ülke ve 4409 şirket üzerinde yaptıkları çalışmada yabancı yatırımcıların iyi kurumsal yönetime sahip, azınlık haklarını koruyan şirketleri tercih ettiklerini belirtmişlerdir. Bu doğrultuda yabancı yatırımcı oranı ile temettü dağıtım oranı arasında pozitif bir ilişki beklenmektedir.

Hacim: Hacim değişkeni, ilgili hisse senedinin yıl boyunca günlük ortalama işlem hacmi miktarının, halka açık hisse senedi sayısına bölünerek elde edilmiştir. Hacim değişkeni, hisse senedinin ne kadar sıklıkla piyasada işlem gördüğünü göstermektedir. Hacim değişkeni ile YYO arasındaki ilişki, yabancı yatırımcıların yatırım ufkunu görebilmemiz için önemlidir. Yabancı yatırımcıların, hisse senedi elde tutma süresinin yerli yatırımcılardan çok daha uzun olduğu düşünüldüğünde, Hacim değişkeni ile YYO arasında negatif bir ilişki olması beklenmektedir. Kang ve diğerleri (2010) yabancı yatırımcıların işlem hacmi düşük şirketleri tercih ettiğini tespit etmiştir.

ihracat: îhracat oranı firmanın yurtdışı satışlarının toplam satışlarına bölünmesi yoluyla elde edilmiştir. Merton (1987) yatırımcıların daha fazla bilgi sahibi oldukları hisse senetlerine yatıım yapma eğiliminde olduklarını tespit etmiştir. Firma büyüklüğünde olduğu gibi yabancı yatıııcılar ihracat oranı yüksek şirketlerin faaliyetleri hakkında daha fazla bilgi sahibi olmakta, bu durum yerli ve yabancı yatırımcılar arasındaki bilgi asimetrisini azaltmakta ve sonuç olarak yabancı yatırımcıları ihracat oranı yüksek firmalara yatırım yapmaya yönlendirmektedir.

Tablo 1'de bağımlı ve bağımsız değişkenlere ait özet istatistikler verilmiştir. Analizin bağımlı değişkeni olan YYO değişkeninin ortalama ve ortanca değerleri 0,21 ve $0,07^{\prime}$ dir. Bu değerler, YYO değişkeninin dağılımının sağa yatık olduğunu göstermektedir. YYO değişkeninin minimum ve maksimum değerleri ise 0 ve $0,98^{\prime}$ dir. Bu 
değerler, bazı hisselerde hiç yabancı yatırımcı olmadığını, bazı hisselerde ise yabancı yatırımcıların büyük çoğunlukta olduğunu göstermektedir.

Çalışmada ele alınan bağımsız değişkenlerin özet istatistikleri incelendiğinde birçok değişkenin ortalama ve ortanca değerlerinin birbirine çok yakın olduğu gözlenmiştir. Tabloda dikkat çeken diğer bir nokta PD/DD değişkeninin minimum ve maksimum değerlerinin $-6,5$ ve 21,2 olmasıdır. PD/DD değerinin negatif olması, bazı şirketlerin öz sermayelerinin defter değerlerinin negatif olmasından kaynaklanmaktadır. Kaldıraç değişkeninin maksimum değerinin 1'den büyük olması da yine bazı şirketlerin öz sermaye defter değerlerinin negatif olduğunun göstergesidir.

Tablo 1: Bağımlı ve Bağımsız Değişkenlere Ait Özet İstatistikler

\begin{tabular}{lccccc}
\hline & Ortalama & Ortanca & Standart Sapma & Minimum & Maksimum \\
\hline YYO & 0,211 & 0,066 & 0,278 & 0,000 & 0,978 \\
PD & 18,970 & 18,830 & 1,710 & 14,577 & 24,172 \\
Karlılık & 0,087 & 0,084 & 0,092 & $-0,333$ & 0,597 \\
PD/DD & 1,514 & 1,121 & 1,582 & $-6,540$ & 21,241 \\
Kaldıraç & 0,443 & 0,431 & 0,226 & 0,006 & 1,609 \\
Temettü & 0,037 & 0,000 & 0,100 & 0,000 & 2,445 \\
Hacim & 0,029 & 0,011 & 0,067 & 0,000 & 0,995 \\
Likidite & 2,629 & 1,635 & 3,988 & 0,032 & 79,249 \\
ihracat & 0,240 & 0,173 & 0,240 & 0,000 & 0,996 \\
\hline
\end{tabular}

Notlar: YYO değeri yıl sonu itibariyle hissedeki yabancı yatırımcı portföy ağılığını ifade etmektedir. PD piyasa büyüklüğünü, Karlılık vergi, faiz ve yıpranma payı öncesi karın toplam varlıklara oranını, PD/DD piyasa değerinin defter değerine oranını, Kaldıraç toplam yükümlülüklerin toplam kaynaklara oranını, Temettü yıl boyunca dağıtılan kar paylarının yılsonu hisse fiyatına oranını, Hacim yıl boyunca gözlemlenen günlük işlem hacmi değerinin toplam hisse senedi sayısına oranını, Likidite kısa vadeli varlıkların kısa vadeli kaynaklara oranını, îhracat yurtdışı satışların toplam satışlara oranını ifade etmektedir.

Tablo 2, analizde kullanılan bütün değişkenlere ait korelasyon değerlerini vermektedir. Korelasyon tablosunun incelenmesi iki açıdan önemlidir. İlk olarak, bağımsız değişkenler arası yüksek korelasyon olması çoklu doğrusal bağlantı göstergesidir ve analiz sonuçlarını önemli ölçüde etkilemektedir. Standart regresyon modellerinde bağımsı değişkenler arası çoklu bağlantı probleminin olmaması temel varsayımlardan biridir. İkinci olarak, korelasyon tablosu bağımlı değişkenle bağımsız değişkenler arası tek yönlü ilişkinin önemli bir göstergesidir. Çok değişsenli analizlere geçilmeden önce korelasyon değerlerinin incelenmesi, bağımlı değişken ile bağımsız değişkenler arasındaki ilişkinin yönü ve kuvveti açısından araştırmacıya ön bilgi sunmaktadır.

Bağımsız değişkenler arasındaki korelasyon değerlerine bakıldığında ise en yüksek değerlerin -0,46 ile Likidite ve Kaldıraç değerleri arasında olduğu gözlenmiştir. Yüksek kaldıraç seviyesine sahip şirketlerin düşük cari orana sahip olması beklenen bir durumdur. Temettü ve Karlılık değişkenleri arasındaki korelasyon 0,35 seviyesindedir. iki değişken arasındaki yüksek korelasyon, karlılık oranı yüksek şirketlerin temettü dağıtım oranlarının da yüksek olduğunun bir göstergesidir. Bütün olarak bağımsız değişkenler arasındaki korelasyon incelendiğinde, analizde çoklu doğrusal bağlantı problemi yaratabilecek değerlere rastlanmamıştır.

Bağımlı değişken ile bağımsız değişkenler arasındaki korelasyon incelendiğinde ise, YYO ile en yüksek korelasyona sahip değişkenin 0,65 ile PD olduğu gözlenmiştir. YYO ile PD arasındaki yüksek korelasyon literatürdeki diğer çalışmaların sonuçları ile benzerlik taşımakta ve yabancı yatırımcıların piyasa değeri büyük şirketleri tercih ettiğini göstermektedir. YYO ile en yüksek korelasyona sahip ikinci değişken 0,28 ile Karlılık'tır. İki değişken arasındaki korelasyonun yüksek ve pozitif olması, yabancı yatırımcıların karlılığı yüksek şirketleri tercih ettiğini göstermektedir.

Beklentinin aksine, YYO ile Kaldıraç arasında pozitif $(0,07)$, Likidite arasında negatif $(-0,10)$ bir ilişki vardır. Literatürde yapılan diğer çalışmalardan farklı olarak, Türkiye'de yabancı yatırımcılar yüksek kaldıraç oranı ve düşük likidite oranına sahip şirketleri tercih etmektedirler. YYO ile Hacim arasındaki ilişki de beklenildiği gibi negatiftir. Yabancı yatırımcı oranı yüksek olan şirketlerin işlem hacmi düşüktür. Yabancı yatırımcıların hisseleri elde tutma süresinin uzun olması, YYO ile işlem hacmi arasındaki ilişkinin negatif yönde olmasının 
nedenlerinden biridir. Analizde kullanılan bütün açıklayıcı değişkenler ile YYO orasındaki korelasyon ilişkisi \%95 güven aralığında anlamlıdır. Bu durum, çalışmaya dahil edilen açıklayıcı değişkenlerin doğru bir şekilde seçildiğinin göstergesidir.

Tablo 2: Korelasyon Değerleri

\begin{tabular}{|c|c|c|c|c|c|c|c|c|c|}
\hline & YYO & (1) & (2) & (3) & (4) & (5) & (6) & (7) & (8) \\
\hline YYO & 1,000 & & & & & & & & \\
\hline (1) PD & $\begin{array}{l}0,646 \\
(0,000)\end{array}$ & 1,000 & & & & & & & \\
\hline (2) Karlılık & $\begin{array}{l}0,280 \\
(0,000)\end{array}$ & $\begin{array}{l}0,406 \\
(0,000)\end{array}$ & 1,000 & & & & & & \\
\hline (3) $P D / D D$ & $\begin{array}{l}0,070 \\
(0,007)\end{array}$ & $\begin{array}{l}0,206 \\
(0,000)\end{array}$ & $\begin{array}{l}0,052 \\
(0,045)\end{array}$ & 1,000 & & & & & \\
\hline (4) Kaldıraç & $\begin{array}{l}0,066 \\
(0,010)\end{array}$ & $\begin{array}{l}-0,059 \\
(0,022)\end{array}$ & $\begin{array}{l}-0,202 \\
(0,000)\end{array}$ & $\begin{array}{l}0,016 \\
(0,542)\end{array}$ & 1,000 & & & & \\
\hline (5) Temettü & $\begin{array}{l}0,088 \\
(0.001)\end{array}$ & $\begin{array}{l}0,168 \\
(0,000)\end{array}$ & $\begin{array}{l}0,353 \\
(0,000)\end{array}$ & $\begin{array}{l}0,052 \\
(0,042)\end{array}$ & $\begin{array}{l}-0,195 \\
(0,000)\end{array}$ & 1,000 & & & \\
\hline (6) Hacim & $\begin{array}{l}-0,137 \\
(0,000)\end{array}$ & $\begin{array}{l}-0,095 \\
(0,000)\end{array}$ & $\begin{array}{l}-0,008 \\
(0,760)\end{array}$ & $\begin{array}{l}0,088 \\
(0,001)\end{array}$ & $\begin{array}{l}-0,003 \\
(0,917)\end{array}$ & $\begin{array}{l}0,196 \\
(0,000)\end{array}$ & 1,000 & & \\
\hline (7) Likidite & $\begin{array}{l}-0,103 \\
(0,000)\end{array}$ & $\begin{array}{l}-0,017 \\
(0,521)\end{array}$ & $\begin{array}{l}0,097 \\
(0,000)\end{array}$ & $\begin{array}{l}0,113 \\
(0,000)\end{array}$ & $\begin{array}{l}-0,463 \\
(0,000)\end{array}$ & $\begin{array}{l}0,082 \\
(0,002)\end{array}$ & $\begin{array}{l}-0,013 \\
(0,625)\end{array}$ & 1,000 & \\
\hline (8) Ihracat & $\begin{array}{l}0,088 \\
(0,001)\end{array}$ & $\begin{array}{l}0,072 \\
(0,005)\end{array}$ & $\begin{array}{l}0,130 \\
(0,000)\end{array}$ & $\begin{array}{l}-0,088 \\
(0,001)\end{array}$ & $\begin{array}{l}0,098 \\
(0,000)\end{array}$ & $\begin{array}{l}0,025 \\
(0,329)\end{array}$ & $\begin{array}{l}0,007 \\
(0,786)\end{array}$ & $\begin{array}{l}-0,094 \\
(0,000)\end{array}$ & 1,000 \\
\hline
\end{tabular}

\section{METODOLOJI VE BULGULAR}

Çalışmada dinamik panel regresyon yöntemleri kullanılmıştır. Dinamik panel regresyon yöntemleri bağımlı ya da bağımsız değişkenlerin gecikmeli değerlerinin de açıklayıcı değişken olarak kullanıldığı modellerdir. Statik modeller bağımsız değişken ile bağımlı değişken arasında eş zamanlı bir ilişki olduğunu varsaymaktadır. Başka bir ifadeyle bağımsız değişkendeki t zamanda yaşanan bir değişim bağımlı değişkende de $t$ zamanda bir etki yaratacağı varsayılmaktadır. Ancak ekonomi ve finans literatüründe ele alınan birçok değişkenin etkisi hemen ortaya çıkmamakta ve en önemlisi bağımlı değişken kendi gecikmeli değerlerinden etkilenebilmektedir. Bu durumda tutarlı ve doğru bir tahmin için bağımlı değişkenin kendi gecikmeli değerinin de modele eklenmesi gerekmektedir. Ayrıca bağımlı değişkenin gecikmeli değerinin modele eklenmesi, tahmin edilen modelin dinamik yapısı ile ilgili önemli bilgiler vermektedir. Son olarak, modelin dinamik bir şekilde tahmin edilmesi, hata terimleri arasında ortaya çıkabilecek serisel korelasyon probleminin de kısmen önüne geçmektedir. Çalışmada kullanılan $\mathrm{YYO}_{\mathrm{t}}$ bağımlı değişkeni ile $\mathrm{YYO}_{\mathrm{t}-1}$ arasındaki korelasyon değeri 0,92 ile oldukça yüksek bir seviyededir. Bu değer, bağımlı değişkeni etkileyen en önemli değişkenin kendi gecikmeli değeri olduğunu ve analizlerde dinamik bir yapının tercih edilmesinin daha doğru sonuçlar doğuracağını ortaya koymaktadır. Başka bir ifadeyle, YYO'nun hisse senedi bazında tutarlı bir seyir izlemesi, yabancı yatırımcıların büyük oranda geçmiş yıldaki kararlarından etkilendiğinin bir göstergesidir.

Çalışma özelinde kullanılacak olan dinamik panel regresyon modeli şu şekilde oluşturulmuştur:

$$
\begin{gathered}
Y Y O_{i, t}=Y Y O_{i, t-1}+K_{i, t}+u_{i, t} \\
u_{i, t}=\mu_{i}+v_{i, t}
\end{gathered}
$$


Modelde yer alan terimlerin açıklamaları şöyledir:

$Y Y O_{i, t}=\mathrm{i}$ firması için t zamandaki yabancı yatırımcı oranı

$Y Y O_{i, t-1}=\mathrm{i}$ firması için $\mathrm{t}-1$ zamandaki yabancı yatırımcı oranı

$K_{i, t}=\mathrm{i}$ hisse senedinin t zamandaki bağımsız değişkenleri

$u_{i, t}=\mathrm{i}$ hisse senedinin $\mathrm{t}$ zamandaki hata terimi

$\mu_{i}=\mathrm{i}$ hisse senedine ait sabit etkiler

$v_{i, t}=\mathrm{i}$ hisse senedinin t zamanına ait bireysel etkiler

Dinamik panel regresyon yöntemlerinin en basit hali standart en küçük kareler (EKK) yöntemleri ile yapılan tahminlerdir. Tablo 3'te (1) numaralı panel, havuzlanmış panel regresyon ${ }^{6}$ analiz sonuçlarını ifade ederken, (2) numaralı panel ise sabit etkiler panel regresyon analizi sonuçlarını göstermektedir. Her iki modelde de zaman etkisini kontrol etme adına yıllara ait kukla değişkenler analize dahil edilmiştir. Tabloda ayrıca, modelin açıklayıcı gücünü gösteren $\mathrm{R}^{2}$ sonucuna ek olarak hata terimlerinin birinci ve ikinci derece otokorelasyon değerleri (AR 1 ve AR 2) de raporlanmıştır.

Tablo 3: Standart EKK Yöntemleri ile Yabancı Yatırımcı Oranı Tahmini

Bağımlı Değişken: YYO

\begin{tabular}{|c|c|c|c|c|}
\hline & \multicolumn{2}{|l|}{ (1) } & \multicolumn{2}{|l|}{ (2) } \\
\hline & Katsayı & $\mathrm{t}$ istatistiği & Katsayı & $\mathrm{t}$ istatistiği \\
\hline $\mathrm{YYO}_{\mathrm{t}-1}$ & 0,859 & $(42,82)^{* * *}$ & 0,434 & $(10,09)^{* * *}$ \\
\hline PD & 0,015 & $(4,72)^{* * *}$ & 0,061 & $(5,00)^{* * *}$ \\
\hline Karlılık & 0,088 & $(1,85)^{*}$ & 0,084 & $(1,50)$ \\
\hline PD/DD & 0,003 & $(1,14)$ & $-0,003$ & $(-0,80)$ \\
\hline Kaldıraç & 0,020 & $(1,50)$ & 0,423 & $(1,15)$ \\
\hline Temettü & $-0,038$ & $(-1,42)$ & $-0,032$ & $(-1,11)$ \\
\hline Hacim & $-0,052$ & $(-1,55)$ & $-0,107$ & $(-1,69)^{*}$ \\
\hline Likidite & $-0,001$ & $(-1,84)^{*}$ & $-0,001$ & $(-1,59)$ \\
\hline İhracat & 0,005 & $(0,36)$ & $-0,026$ & $(-0,73)$ \\
\hline Yıl Etkisi & Evet & & Evet & \\
\hline Firma Etkisi & Hayır & & Evet & \\
\hline $\mathrm{R}^{2}$ & 0,86 & & 0,90 & \\
\hline AR 1 & $-1,70^{*}$ & & 0,38 & \\
\hline AR 2 & 1,11 & & $-1,35$ & \\
\hline \multicolumn{5}{|c|}{$\begin{array}{l}\text { Notlar: Modelde heterojen varyans probleminden dolayı White standart hata düzeltmesi } \\
\text { uygulanmıştır. }{ }^{* * *},{ }^{* *} \text { ve }{ }^{*} \text { sembolleri } \% 1, \% 5 \text { ve } \% 10 \text { seviyesinde anlamlılık değerlerini ifade } \\
\text { etmektedir. Bağımlı değişkenin gecikmeli değeri analize dahil edildiği için modellerde örneklem } \\
\text { büyüklüğü } 1359 \text { 'a düşmüştür. }\end{array}$} \\
\hline
\end{tabular}

Havuzlanmış EKK yöntemi her ne kadar basit ve sık kullanılan bir yöntem olsa da, model sonuçları hatalıdır. Bu yöntemle ile ilgili ilk göze çarpan problem literatürede "dinamik panel yanılgısı" ya da "Nickell yanılgısı" olarak geçen içsellik problemidir (Nickell, 1981). Modelin yapısı gereği $\mathrm{YYO}_{\mathrm{t}-1}$ ile $\mu_{i}$ yani modelin sabit etkileri ilişkilidir. Bu durum elde edilen katsayıların hatalı olmasına neden olmaktadır. Çalışmada kurulan modelden bir örnek vermek gerekirse, 2008 yılında bir firmanın yabancı yatırımcılar ile ilgili bir şok yaşaması, modelin hata terimlerine yansıyacaktır. Diğer bütün etkiler sabit tutulduğunda, firmaya ait sabit etki 2005-2014 yılları arasında olması gerekenden daha düşük olacaktır. 2009 yılına gelindiğinde ise hem $\mathrm{YYO}_{\mathrm{t}-1}$ hem de $\mu_{i}$ olması

\footnotetext{
${ }^{6}$ Havuzlanmış EKK yönteminde firmalara ait kukla değişkenler analize dahil edilmemiştir.

${ }^{7}$ Nickell bias
} 
gerekenden daha düşük ve ilişkili olacaktır. $\mathrm{YYO}_{\mathrm{t}-1}$ ile $\mu_{i}$ arasındaki pozitif korelasyon EKK yöntemlerinin varsayımlarından biri olan, bağımsız değişkenler ile hata terimleri arasındaki korelasyonun 0 olma durumunu ihlal edecektir. Sonuç olarak bu ihlal, YYO'nun bir gecikmeli değerinin yani $\mathrm{YYO}_{\mathrm{t}-1}$ 'in katsayısının $(0,859)$ olması gerekenden büyük olmasına neden olacaktır.

$\mathrm{YYO}_{\mathrm{t}-1}$ ile sabit etkiler arasındaki korelasyondan kaynaklanan içsellik problemini ortadan kaldırmaya yönelik ilk tepki, modele firmaya özgü kukla değişkenler eklenmesidir. Firmaya özgü kukla değişkenler eklenerek sabit etkiler saf dışı bırakılır. Tablo 3, Panel 2, firmalara ait kukla değişkenler eklendikten sonra uygulanan sabit etkiler panel regresyon modeli tahmin sonuçlarını vermektedir.

Her ne kadar modele firmalara ait kukla değişkenler eklenerek modeldeki içsellik problemin önüne geçilmeye çalışılsa da "dinamik panel yanılgısı"nın tam olarak ortadan kalktığını söylemek mümkün değildir (Nickell, 1981; Bond, 2002). Firmaya özgü kukla değişkenler modele eklense dahi bağımsız değişken ile hata terimi birbiri ile ilişkili olacaktır. Bu durumda bağımlı değişkenin gecikmeli değerine (çalışmada kullanılan modelde $\mathrm{YYO}_{\mathrm{t}-1}$ ) ait tahmin edilen katsayı değeri $(0,434)$ olması gerekenden küçük bir değer olacaktır.

Kısaca özetlemek gerekirse, EKK ile tahmin edilen hem havuzlanmış hem de firmalara ait kukla değişkenlerin eklendiği sabit etkiler panel regresyon yöntemi içsellik probleminden dolayı hatalı katsayılar tahmin edecektir. Her ne kadar tahminler hatalı olsa da, bu iki model, doğru tahmin yöntemi hakkında önemli ipuçları vermektedir. Havuzlanmış regresyon yöntemi ile tahmin edilen $\mathrm{YYO}_{\mathrm{t}-1}$ değerine ait katsayının $(0,859)$ olması gerekenden büyük, firmaya özgü kukla değişkenlerin eklendiği panel regresyon yönteminden elde edilen $\mathrm{YYO}_{\mathrm{t}-1}$ değerine ait katsayının $(0,434)$ olması gerekenden küçük olduğu daha önce belirtilmişti. Bu doğrultuda, doğru modelin $\mathrm{YYO}_{\mathrm{t}-1}$ terimi için katsayı değeri 0,872 ile 0,448 arasında olması gerekmektedir (Bond, 2002). Kısacası, EKK yöntemleri her ne kadar yanlı sonuçlar da verse, alternatif model tahminlerine geçilmeden önce EKK yöntemlerinin ön test olarak tahmin edilmesi, doğru sonuçlara ulaşmada önemli bir adımdır.

Buraya kadar bahsedilen içsellik problemlerine ilk ciddi çözüm Anderson ve Hsiao (1982) tarafından getirilmiştir. Anderson ve Hsiao modelinde firmaya özgü etkilerin ortadan kaldırılması için değişkenlerin birinci derece farkları alınarak tahmin yapılır. Model içerisinde üretilen araç değişkenlerin kullanılarak iki aşamalı regresyon tahmini öneren Anderson ve Hsiao, modeldeki içsellik probleminin önüne geçebilmek adına birinci dereceden farkları alınmış bağımlı değişkenin gecikmeli değeri olan $\Delta \mathrm{YYO}_{\mathrm{i}, \mathrm{t}-1}$ için $\Delta \mathrm{YYO}_{\mathrm{i}, \mathrm{t}-2}$ ya da $\mathrm{YYO}_{\mathrm{i}, \mathrm{t}-2}{ }^{\prime}$ nin araç değişken olarak kullanılmasını önermişlerdir. Burada dikkat edilmesi gereken nokta kullanılacak araç değişkenlerin bağımsız değişken ile korelasyonu yüksek ve hata terimi ile korelasyonu düşük olmasıdır. Yanlış araç değişkenlerin kullanılması model tahmininden elde edilecek sonuçlardaki hataların daha büyük olmasına neden olabilir. Anderson ve Hsiao $(\mathrm{AH})$ modelinde, $\mathrm{YYO}_{\mathrm{i}, \mathrm{t}-2}$ ve $\Delta \mathrm{YYO}_{\mathrm{i}, \mathrm{t}-2}$ 'nin $\Delta \mathrm{YYO}_{\mathrm{i}, \mathrm{t}-1}$ ile ilişkili ancak $\Delta v_{i, t}$ ile ilişkisiz olduğu düşünüldüğünde, önerilen modelin EKK modellerinde ortaya çıkan içsellik probleminin önüne geçebileceği ve EKK modellerine göre daha iyi sonuçlar vereceği beklenmektedir. Dikkat edilmesi gereken diğer bir nokta da, Anderson ve Hsiao'nın önerdiği iki aşamalı araç değişkenli modelin tutarlı sonuçlar vermesi için $\Delta v_{i, t}$ 'nin ikinci derece otokorelasyon problemi yaşamaması gerekliliğidir. Tablo 4, Panel $1 \mathrm{AH}$ tahmin sonuçlarını göstermektedir.

Modeldeki içsellik problemini ortadan kaldıramaya yönelik diğer bir çözüm de Genelleştirilmiş Momentler Yöntemi (GMM) tahminidir. GMM yöntemi Holtz-Eakin ve diğerleri (1988), Arellano-Bond (1991), Arellano ve Bover (1995) ve Blundell ve Bond (1998) tarafından geliştirilen, yatay kesit boyutunun uzun (büyük N) ve zaman boyutunun kısa (küçük T) olduğu panel veri setleri için geliştirilmiştir. GMM yöntemi bağımsız değişkenlerin kendi gecikmeli değerleri ya da sabit etkilerle ilişkili olduğu durumlarda modelde karşılaşılabilecek değişen varyans ve otokorelasyon problemlerini dikkate alan özel bir yöntemdir.

$\mathrm{AH}$ modelinde $\Delta \mathrm{YYO}_{\mathrm{t}-1}$ ile $\Delta \mathrm{u}_{\mathrm{t}}$ arasındaki korelasyona çözüm olarak $\Delta \mathrm{YYO}_{\mathrm{t}-1}$ için $\mathrm{YYO}_{\mathrm{t}-2}$ değişkeni araç değişken olarak kullanılmıştı. GMM yönteminde amaç, modele daha fazla bilgi vererek modelin etkinliğini artırmaktır. Başka bir ifadeyle, $\triangle \mathrm{YYO}_{\mathrm{t}-1}$ için, sadece $\mathrm{YYO}_{\mathrm{t}-2}$ değil $\mathrm{YYO}_{\mathrm{t}-3}, \mathrm{YYO}_{\mathrm{t}-4}$ ve sonraki bütün gecikmeli değerler de araç değişken olarak kullanılarak modelin etkinliği arttırılabilir. Ancak AH modelinde kullanılacak olan her gecikmeli değer için örneklem daha da azalacaktır. Bu durumda araştırmacı, modele daha fazla gecikmeli değer ekleyerek modelin etkinliğini arttırma ile örneklemin küçülmesi arasında bir tercih yapma durumunda kalacaktır. Holtz- 
Eakin ve diğerleri (1988) araç değişkenli modellerde ortaya çıkan bu sorunu giderme adına GMM yöntemini geliştirmişlerdir.

Holtz-Eakin (1988) bu soruna çözüm olarak araç değişken olarak $\mathrm{YYO}_{\mathrm{t}-2}$ ve sonraki bütün gecikmeli değerleri ekleyip eksik gözlemlerin yerine de "0" koyarak GMM tarzı araç değişkenler matrisini oluşturmuşlardır. GMM yöntemi araştırmacının gecikme uzunluğu ile örneklem büyüklüğü arasında tercih yapma durumunu ortadan kaldırmıştır. GMM yönteminde, içsel olduğu düşünülen bütün açıklayıcı değişkenler için, uygun olan bütün gecikmeli değerler araç değişken olarak modele dahil edilebilecektir. Ancak araç değişken sayısı kuadratik olduğu için, özellikle zaman serisinin uzun ve açıklayıcı değişken sayısının fazla olduğu durumlarda bütün gecikmeli değerlerin araç değişken olarak kullanılması modelin etkinliğini ve araç değişkenlerin uygunluğunu gösteren Sargan/Hansen testinin başarısını azaltacaktır. Bu yüzden gecikmeli değer uzunluğu doğru bir şekilde seçilmeli, araç değişkenlerin uygunluğunu gösteren Sargan/Hansen testi doğru yorumlanmalı ve modelde kullanılan araç değişken sayısı mutlaka raporlanmalıdır.

Tablo 4 Panel 2, GMM yöntemi ile yapılan tahmin sonuçlarını göstermektedir. AH modelinde olduğu gibi tahmin birinci derece farklar alınarak yapılmıştır. GMM modelinde $\Delta \mathrm{YYO}_{\mathrm{t}-1}$ için $\mathrm{YYO}_{\mathrm{t}-2}$ ve sonraki bütün gecikmeli değerleri araç değişken olarak kullanılmıştır. Diğer açıklayıcı değişkenler ise AH modelinde olduğu gibi dışsal değişkenler olarak modele dahil edilmiştir.

Tablo 4: AH (Anderson-Hsiao) ve GMM Yöntemleri ile Yabancı Yatırımcı Oranı Tahmini

Bağımlı Değişken: YYO

\begin{tabular}{|c|c|c|c|c|}
\hline & \multicolumn{2}{|c|}{ (1) AH Tahmini } & \multicolumn{2}{|c|}{ (2) GMM Tahmini } \\
\hline & Katsayı & z istatistiği & Katsayı & t istatistiği \\
\hline $\mathrm{YYO}_{\mathrm{t}-1}$ & 0,447 & $(2,17)^{* *}$ & 0,600 & $(4,56) * * *$ \\
\hline PD & 0,076 & $(6,01)^{* * *}$ & 0,075 & $(4,70)^{* * *}$ \\
\hline Karlılık & 0,002 & $(0,04)$ & $-0,001$ & $(-0,01)$ \\
\hline PD/DD & $-0,005$ & $(-1,56)$ & $-0,004$ & $(-1,07)$ \\
\hline Kaldıraç & 0,007 & $(0,16)$ & 0,003 & $(0,04)$ \\
\hline Temettü & $-0,062$ & $(-1,75)^{*}$ & $-0,055$ & $(-1,33)$ \\
\hline Hacim & $-0,092$ & $(-1,44)$ & $-0,103$ & $(-1,71)^{*}$ \\
\hline Likidite & $-0,001$ & $(-2,25)^{* *}$ & $-0,001$ & $(-1,77)^{*}$ \\
\hline İhracat & $-0,022$ & $(-0,71)$ & $-0,036$ & $(-0,89)$ \\
\hline Yıl Etkisi & Evet & & Evet & \\
\hline AR 1 & $-2,57 * * *$ & & $-3,38 * * *$ & \\
\hline AR 2 & $-0,48$ & & $-0,16$ & \\
\hline Hansen testi & - & & 34,28 & \\
\hline Araç değişken sayısı & - & & 27 & \\
\hline \multicolumn{5}{|c|}{$\begin{array}{l}\text { Notlar: Bütün modeller birinci derece farklar alınarak tahmin edilmiştir. AH Modelinde (Panel } 1) \mathrm{YYO}_{\mathrm{t}-2} \\
\text { değişkeni } \Delta \mathrm{YYO}_{\mathrm{t}-1} \text { için araç değişken olarak kullanılmıştır. GMM modelinde (Panel } 2 \text { ) ise } \mathrm{YYO}_{\mathrm{t}-2} \text { ve } \\
\text { sonraki bütün gecikmeli değerleri araç değişken olarak kullanılmıştır. Modelin hata terimleri heterojen } \\
\text { varyans problemine karşı düzeltilmiştir. } * * *, * * \text { ve } * \text { sembolleri } \% 1, \% 5 \text { ve } \% 10 \text { seviyesinde anlamlık } \\
\text { değerlerini ifade etmektedir. Model birinci derece fark cinsinden tahmin edildiği ve bağımlı değişkenin } \\
\text { gecikmeli değeri analize dahil edildiği için modellerde örneklem büyüklüğü } 1208^{\prime} \text { e düşmüştür. }\end{array}$} \\
\hline
\end{tabular}

Analiz sonuçlarına geçmeden önce, AH ve GMM modellerinin uygunluk sınaması yapılması gerekmektedir. Tablo 4'te görüldüğü gibi $\mathrm{YYO}_{\mathrm{t}-1}$ değeri her iki modelde de daha önce belirlenen güven aralığının içerisindedir. Her iki modelde de ikinci derece otokorelasyon problemli bulunmamaktadır. Son olarak, GMM modelinde kullanılan araç değişkenlerin uygunluğunu belirten Hansen testi ${ }^{8}$ sonucunun anlamsız olması, modelde kullanılan araç değişkenlerin parametre tahmini için uygun olduğunu göstermektedir. Özetle, YYO tahmini için kurulan her iki yöntem de model tahmini için uygundur.

\footnotetext{
${ }^{8}$ Hansen testi'nin sıfır hipotezi “araç değişkenler uygundur” şeklindedir.
} 
$\mathrm{AH}$ ve GMM tahmin sonuçlarında ilk dikkat çeken nokta bağımlı değişkenin gecikmeli değeridir. $\mathrm{YYO}_{\mathrm{t}-1}$ değişkeni $\mathrm{AH}$ modelinde \%5, GMM modelinde ise \%1 seviyesinde anlamlıdır. Bu sonuç, yabancı yatırımcı tercihlerinin büyük oranda geçmiş yıl kararlarından etkilendiğini göstermektedir. Her iki modelde de, yabancı yatırımcı oranı ile firmaların piyasa değeri arasında \%1 seviyesinde pozitif anlamlı bir ilişki vardır. Başka bir ifadeyle, Türkiye'deki yabancı yatırımcılar piyasa değeri büyük şirketleri tercih etmektedirler. Bu sonuç literatürdeki diğer çalışmalar ile uyumludur. Yerli ve yabancı yatırımcılar arasındaki bilgi asimetrisinden dolayı, yabancı yatırımcılar kendilerine daha fazla aşina olan ve daha fazla bilgi sahibi oldukları şirketlere portföylerinde yer vermektedirler. Aşina olma ile yatırım davranışı arasındaki ilişki ile ilgili diğer bir gösterge de firmaların ihracat oranıdır. İhracat oranı yüksek olan şirketlerin yabancı yatırımcılar tarafından daha fazla tanınabileceği düşünülse de, yabancı yatırımcı oranı ile ihracat oranı arasında anlamlı bir ilişki bulunamamıştır. Bu sonucun altında yatan temel neden Türkiye'deki şirketlerin ihracat oranlarının düşük seviyelerde olması olabilir. Diğer bir muhtemel açıklama ise, özellikle gelişmekte olan ülkelere yatırım yapan yabancı yatırımcılar için piyasa büyüklüğünün ihracat oranına göre firmalarla ilgili daha güvenilir bir gösterge olmasıdır.

Yabancı yatırımcı oranı ile diğer firmaya özgü faktörler arasındaki incelendiğinde, YYO ile firmanın likiditesi yani cari oranı arasında negatif bir ilişki olduğu göze çarpmaktadır. YYO ile Likidite arasında AH modeline göre \%5 seviyesinde anlamlı negatif bir ilişki vardır. GMM modeli sonuçlarına göre Likidite değişkeninin anlamlılığı azalsa da negatif ilişki \%10 seviyesinde devam etmektedir. Cari oranı yüksek olan şirketlerin ihtiyatlı bir çalışma sermayesi yönetim politikası uyguladığı düşünüldüğünde, Türkiye'deki yabancı yatırımcıların yatırım kararlarında güvenlik unsurundansa kazanç unsuru üzerinde durduğu söylenebilir. Başka bir ifadeyle, gelişmekte olan ülkelere yatırım yaparak yüksek risk seviyesinde yüksek getiri hedefleyen yatırımcı firma tercihinde de benzer şekilde cari oranı düşük şirketlere yatırım yaparak yüksek kazanç arayışı içerisindedir.

Temettü verim oranı ve işlem hacmi ile yabancı yatırımcı oranı arasında her ne kadar her iki model sonucuna göre negatif bir ilişki tespit edilse de, elde edilen sonuçların anlamlılık seviyesi düşüktür. AH modeline \%10 seviyesinde anlamlı olan Temettü değişkeni GMM modelinde anlamsız iken, GMM modelinde anlamlı olan Hacim değişkeni AH modeline anlamsızdır. Son olarak, Karlılık, PD/DD ve Kaldıraç ile yabancı yatırımcı tercihleri arasında anlamlı bir ilişki tespit edilememiştir.

\section{SONUÇ}

Uluslararası sermaye hareketlerinin 1980'ler sonrası dönemde hız kazanmasının altında yatan en büyük nedenlerden biri ülkelerin sermaye hesaplarının liberal hale gelmesidir. ABD ve İngiltere'de başlayan deregülasyon faaliyetleri 1990'lar ile birlikte diğer gelişmiş ve gelişmekte olan ülkeleri de etkilemiş ve birçok ülke finansal serbestleşme hareketlerine hız vermiştir. Türkiye de tüm dünyada etkisini gösteren serbestleşme hareketlerine ayak uydurmuş ve özellikle 1980, 1982 ve son olarak 1989 yılında çıkan yönetmeliklerle birlikte yerel piyasalar yabancı sermayeye açık hale gelmiştir. Finansal serbestleşme hareketleri sonrası hız kazanan uluslararası sermaye akımları beraberinde bu akımların belirleyici unsurları üzerindeki ilgiyi de arttırmıştır. Literatürde yapılan birçok çalışmada hem ülke hem de firma seviyesinde yabancı yatırımcı tercihlerini etkileyen faktörleri tespit edilmeye çalışıımıştır. Bu çalışmalardan elde edilen sonuçlar, yerli ve yabancı yatırımcılar arasındaki bilgi asimetrisinden dolayı yatırımcıların sermayelerini daha fazla aşina ve bilgi sahibi oldukları ülkelere ya da firmalara yönlendirdiklerini göstermektedir.

2005-2014 yılları arasında Borsa İstanbul'a kote 151 finansal olmayan şirket ve 1510 gözlemi içeren bu çalışmanın temel amacı yabancı yatırımcı tercihlerini etkileyen firmaya özgü faktörlerin tespit edilmesidir. Çalışmadan elde edilen sonuçlar, literatürdeki diğer çalışma sonuçlarına paralel şekilde Türkiye'de yabancı yatırımcıların piyasa değeri büyük şirketleri tercih ettiğini göstermektedir. Yerel piyasalar hakkında bilgi dezavantajı olduğu düşünülen yabancı yatırımcılar daha güvenilir gördükleri piyasa değeri büyük şirketleri tercih etmektedirler. Çalışmadan elde edilen diğer bir sonuç da, yabancı yatırımcıların yüksek kazanç beklentisinden dolayı likidite seviyesi düşük şirketleri tercih ettikleridir. Yabancı yatırımcı tercihleri ile diğer firmaya özgü değişkenler arasında tutarlı ve anlamlı bir ilişki tespit edilememiştir.

Çalışmadan elde edilen bulgular, birçok açıdan hem bireysel ve kurumsal yatırımcılar hem de yatırıma ev sahipliği yapan ülkeler ve şirketler için önemlidir. Özellikle Türkiye gibi yerel tasarruf oranı düşük gelişmekte olan ülkelerin en önemli finansman kaynağı yabancı sermayedir. Yabancı sermayeyi kendisine çekmek isteyen 
bir ülke ya da firmanın da öncelikle tespit etmesi gereken yabancı yatırımcıların yatııım tercihlerini etkileyen faktörlerin ne olduğu ve bu faktörlerin nasıl belirlendiğidir. Literatürde diğer ülkelerde yapılan birçok çalışmada bu faktörlerin ne olduğu tespit edilmeye çalışılsa da, Türkiye'de son yıllarda yabancı yatırımcıların hangi firmaları tercih ettiğine yönelik çalışma sayısı oldukça azdır. Bu çalışma ile Türkiye'deki yabancı yatıımcı kararlarını etkileyen faktörler tespit edilmiş ve bu etkilerin muhtemel nedenleri açıklanmaya çalışılmıştır. Sonraki çalışmalarda, bu çalışmada ele alınan firmaya özgü değişkenlere ek olarak yabancı yatıımıı kararlarını etkileyebilecek diğer firmaya özgü değişkenler (kurumsal yönetim kalitesi, hisse senetlerine ait geçmiş performans değerleri vb.) ve makroekonomik göstergeler de analize dahil edilerek bu çalışmadan elde edilen sonuçlar geliştirilebilir.

\section{KAYNAKÇA}

Aggarwal, R., Klapper, L., \& Wysocki, P. D. (2005). Portfolio preferences of foreign institutional investors. Journal of Banking \& Finance, 29(12), 2919-2946.

Anderson, T. W., \& Hsiao, C. (1982). Formulation and estimation of dynamic models using panel data. Journal of econometrics, $18(1)$, 47-82.

Arellano, M., \& Bond, S. (1991). Some tests of specification for panel data: Monte Carlo evidence and an application to employment equations. The review of economic studies, 58(2), 277-297.

Arellano, M., \& Bover, O. (1995). Another look at the instrumental variable estimation of error-components models. Journal of econometrics, 68(1), 29-51.

Asgharian, H. (2003). Are highly leveraged firms more sensitive to an economic downturn?. The European Journal of Finance, 9(3), $219-241$.

Bencivenga, V., Smith, B., \& Starr, R. M. (1992). Liquidity of Secondary Capital Markets: Allocative Efficiency and the Maturity of the Capital Stock(No. 326). University of Rochester-Center for Economic Research (RCER).

Blundell, R., \& Bond, S. (1998). Initial conditions and moment restrictions in dynamic panel data models. Journal of econometrics, 87(1), 115-143.

Bond, S. R. (2002). Dynamic panel data models: a guide to micro data methods and practice. Portuguese economic journal, 1(2), $141-162$.

Dahlquist, M., \& Robertsson, G. (2001). Direct foreign ownership, institutional investors, and firm characteristics. Journal of Financial Economics, 59(3), 413-440.

Dahlquist, M., Pinkowitz, L., Stulz, R. M., \& Williamson, R. (2003). Corporate governance and the home bias. Journal of Financial and Quantitative Analysis,38(01), 87-110.

Edison, H. J., \& Warnock, F. E. (2004). US investors' emerging market equity portfolios: a security-level analysis. Review of Economics and Statistics, 86(3), 691-704.

Evans, K. (2002). Attractive foreign direct investment for development. Global fórum on international investment.

Fama, E. F., \& French, K. R. (1992). The cross-section of expected stock returns. the Journal of Finance, 47(2), 427-465.

Giannetti, M., \& Simonov, A. (2006). Which investors fear expropriation? Evidence from investors' portfolio choices. The Journal of finance, 61(3), 1507-1547.

Glossary, O. E. C. D. (2003). OECD Glossary of Statistical Terms.

Gökkent, Gıyas M. (1997). Theory of Foreign Portfolio Investment. Florida International University. Phd dissertation.

Greenwood, J., \& Jovanovic, B. (1989). Financial development, growth, and the distribution of income (No. w3189). National Bureau of Economic Research.

Hao, J. (2004, January). Foreign ownership and equity returns: Evidence from Japan. In 17th Australasian Finance and Banking Conference (pp. 15-17).

Hargis, K. (1998). Do foreign investors stimulate or inhibit stock market development in Latin America?. The Quarterly Review of Economics and Finance, 38(3), 303-318.

Hargis, K., \& Ramanlal, P. (1998). When does internationalization enhance the development of domestic stock markets?. Journal of Financial Intermediation,7(3), 263-292.

Holtz-Eakin, D., Newey, W., \& Rosen, H. S. (1988). Estimating vector autoregressions with panel data. Econometrica: Journal of the Econometric Society, 1371-1395.

IMF (1998), World Economic Outlook. http://www.imf.org/external/pubs/ft/weo/weo0598/pdf/0598ch1.pdf. 
IMF (2013), Annual Report. https://www.imf.org/external/pubs/ft/ar/2013/eng/pdf/ar13 eng.pdf.

Kandır, S. Y. (2008). Yabancı Yatırımcıların Türkiye'deki Yatırım Tercihlerinin Araştırılması. Muhasebe ve Finansman Dergisi, 38, $199-209$.

Kang, H. C., Lee, D. W., \& Park, K. S. (2010). Does the difference in valuation between domestic and foreign investors help explain their distinct holdings of domestic stocks?. Journal of Banking \& Finance, 34(12), 2886-2896.

Kang, J. K. (1997). Why is there a home bias? An analysis of foreign portfolio equity ownership in Japan. Journal of Financial Economics, 46(1), 3-28.

Kargi, B. (2014). Portfolio in Turkish economy, and a long termed relation between foreign direct investments and the growth, and the structural breakage analysis (1980-2012). Journal of Academic Research in Economics, 6(1), 70-81.

King, R. G., \& Levine, R. (1993). Finance and growth: Schumpeter might be right. The quarterly journal of economics, $717-737$.

La Porta, R., Lopez-de-Silanes, F., Shleifer, A., \& Vishny, R. (2000). Investor protection and corporate governance. Journal of financial economics, 58(1), 3-27.

Leuz, C., Lins, K. V., \& Warnock, F. E. (2010). Do foreigners invest less in poorly governed firms?. Review of Financial Studies, 23(3), 32453285.

Levine, R., \& Zervos, S. (1996). Stock market development and long-run growth. The World Bank Economic Review, 10(2), 323-339.

Liljeblom, E., \& Löflund, A. (2005). Determinants of international portfolio investment flows to a small market: empirical evidence. Journal of multinational financial management, 15(3), 211-233.

Lin, C. H., \& Shiu, C. Y. (2003). Foreign ownership in the Taiwan stock market-an empirical analysis. Journal of Multinational Financial Management, 13(1), 19-41.

Merton, R. C. (1987). A simple model of capital market equilibrium with incomplete information. The journal of finance, 42(3), 483-510.

Min, B. S., \& Bowman, R. G. (2015). Corporate governance, regulation and foreign equity ownership: Lessons from Korea. Economic Modelling, 47, 145-155.

Nickell, S. (1981). Biases in dynamic models with fixed effects. Econometrica: Journal of the Econometric Society, $1417-1426$.

Opler, T. C., \& Titman, S. (1994). Financial distress and corporate performance. The Journal of Finance, 49(3), 1015-1040.

Pagano, M. (1989). Trading volume and asset liquidity. The Quarterly Journal of Economics, 255-274.

TCMB. (2005). Ödemeler Dengesi Raporu. 